Rapp. Grønlands geol. Unders. 81, 15-33 (1977)

\title{
NATIVE IRON BEARING INTRUSIONS OF THE HAMMERS DAL COMPLEX, NORTH-WEST DISKO
}

\author{
Finn Ulff-Møller
}

\section{Introduction}

In the area between Hammers Dal and Gieseckes Dal on north-west Disko (fig. 10) several native iron bearing intrusions have been found over the years (Münther, 1952, 1973; Pedersen, 1975a). Most of these intrusions were formed at shallow depths as volcanic necks of iron-bearing, highly contaminated intermediate rocks, which probably served as feeders for the lavas of the Niaqússat member of the Maligât Formation (Pedersen, 1975a). In addition a series of interconnected subvolcanic intrusions of a very unusual type - the Hammers Dal Complex (Pedersen, 1975a) - were found in 1972 in the south-facing slopes

Fig. 10. Simplified map of north-west Disko based mainly on data from the geological map sheet $70 \mathrm{~V} .1$ $S$ (Qutdligssat). Niaqússat, Nordfjord and Rinks Dal members constitute the Maligât Formation (Hald \& Pedersen, 1975) of which the two former are not distinguished here.

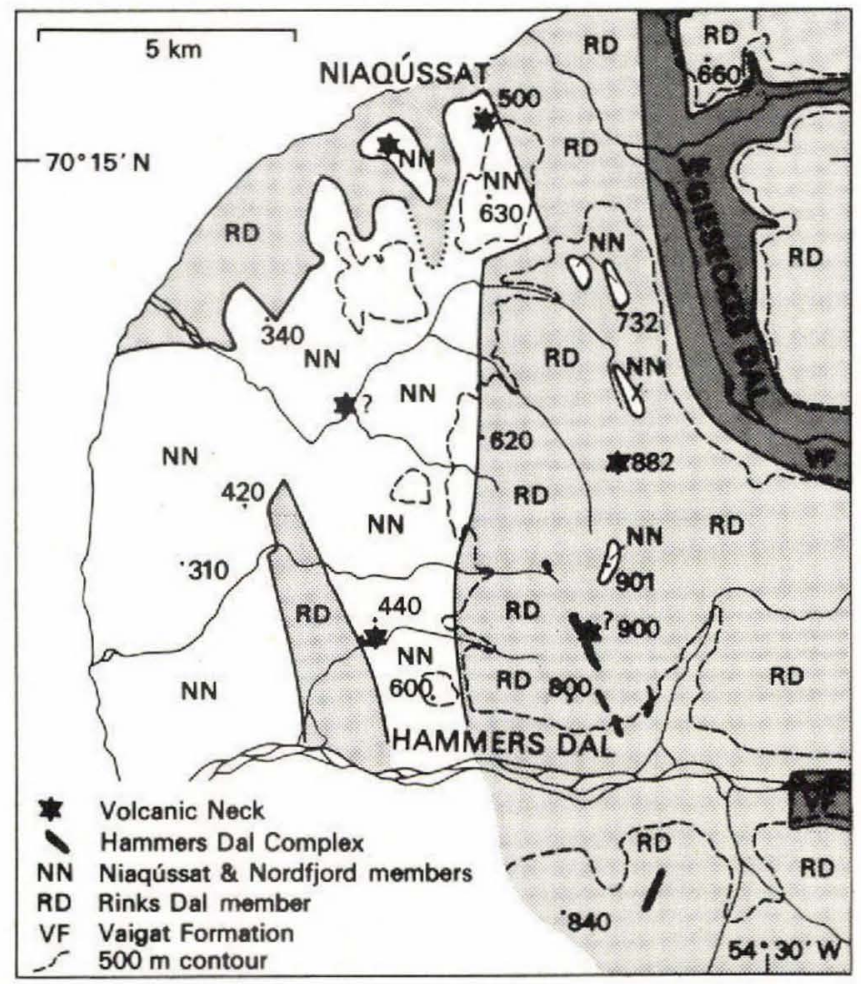



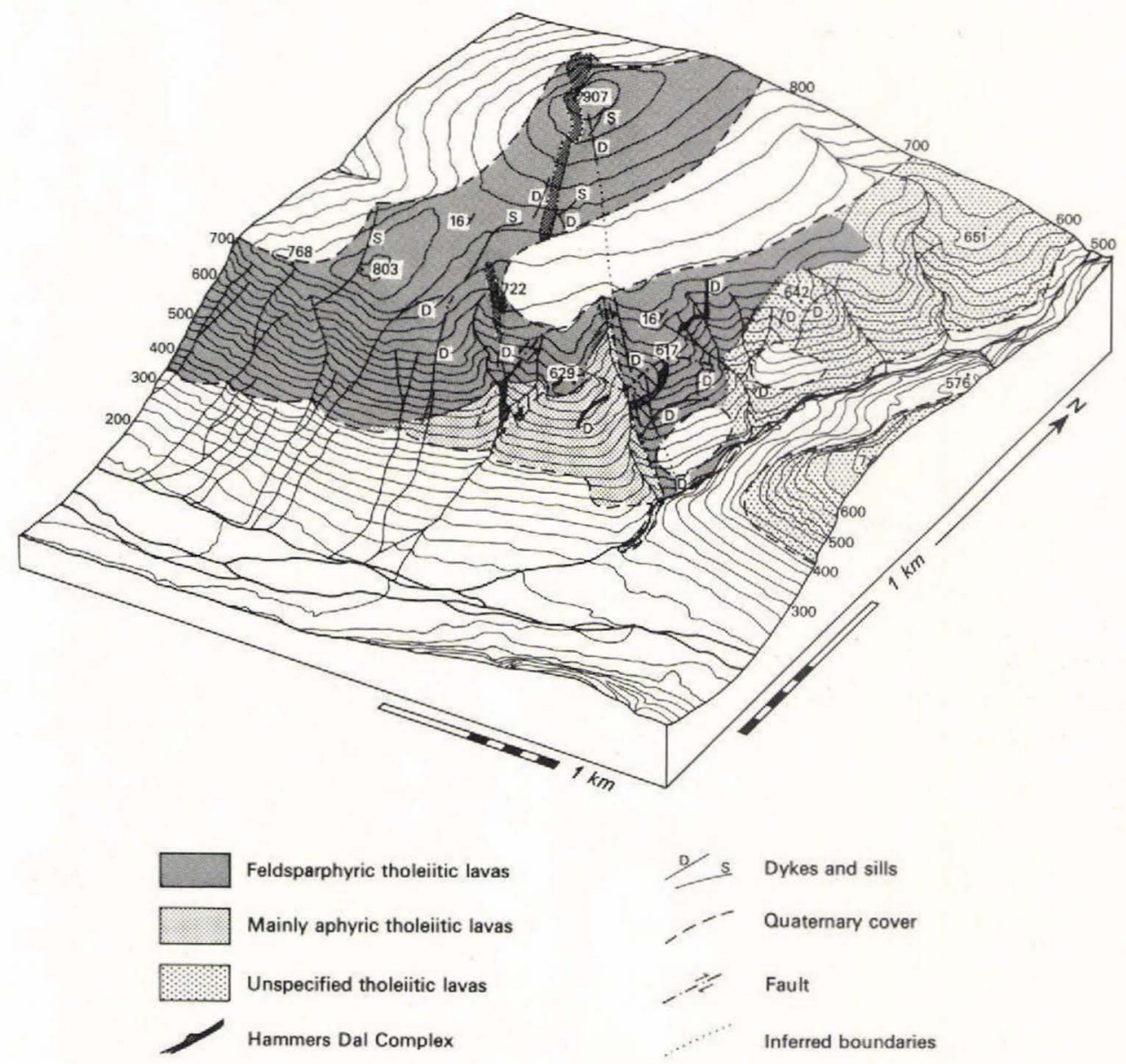

Fig. 11. Block diagram showing the Hammers Dal Complex (the northernmost and southernmost outcrops are omitted) and surrounding country. Hammers Dal in the foreground. Construction based on data from Plate 2.

of Hammers Dal extending a few kilometres towards the north-north-west (fig. 11 and Plate 2). Nickel and copper-bearing pyrrhotite mineralization was associated with the wall rock of the intrusions and cumulate zones of native iron were found in the intrusions themselves. As these were of potential economic interest a detailed investigation of the complex was desirable. [A preliminary description of the Hammers Dal Complex has already been given by Ulff-Møller (1975)].

\section{Spatial relations of the intrusions}

The Hammers Dal Complex comprises a series of intrusions emplaced into a monotonous sequence of tholeiitic 'aa' lavas of the upper part of the Rinks Dal member (Pedersen, 1975a) of the Maligât Formation (Hald \& Pedersen, 1975). In general the intrusions seem to 
be restricted to a plane striking $155-160^{\circ}$ and dipping about $80^{\circ} \mathrm{W}$. Scattered exposures along this zone indicate a lateral extension of the Hammers Dal Complex of at least $7 \mathrm{~km}$.

From a tectonic point of view the north-western part of Disko shown on fig. 10 is broadly divided into a relatively stable plateau in the east where the dip of the lavas rarely exceeds $5^{\circ}$ and an area in the west where intensive block-faulting has taken place (Pedersen, 1975a). These areas are separated from each other by an approximately N-S striking fault zone (not shown on fig. 10). East of this the uppermost part of the Vaigat Formation (Hald \& Pedersen, 1975) is exposed in the bottoms of the valleys and the dip of the lavas of the plateau increases to $70^{\circ} \mathrm{W}$ near this fault zone. West of this the lavas are downfaulted and tilted towards the west and lavas of the Maligât Formation are nearly the only lavas exposed. The downward displacement of the western block comprising point 900 and $901^{*}$ is probably of the order of $500-1000 \mathrm{~m}$ relative to that to the east.

A few kilometres west of the fault zone the lavas dip $11^{\circ} \mathrm{W}$, the dip increasing to $15^{\circ} \mathrm{W}$ immediately west of this (Plate 2). This variation is thought to be an effect of drag folding associated with the fault movements. Further west towards the coast a small part of the succession is repeated several times by faulting while the dip of the lavas increases to $35^{\circ} \mathrm{W}$ (Pedersen, 1975a).

In order to establish the magnitude of local fault movements in the vicinity of the Hammers Dal Complex the boundary between a series of aphyric to slightly plagioclaseporphyritic tholeiites and a concordantly overlying series of plagioclase-augite-olivineglomerophyric tholeiites was used as a marker horizon (figs 11-13b and Plate 2). The latter unit constitutes the uppermost part of the Rinks Dal member and its thickness is estimated to be a minimum of $500 \mathrm{~m}$. This unit may correspond to a sequence of plagioclaseglomerophyric lavas at a similar stratigraphical level on the northern part of Disko (Pedersen, 1973, uppermost part of unit 8).

On the plateau south of Hammers Dal and on strike with the intrusive complex a quantity of blocks of xenolith-rich intermediate rocks were found within a limited area along a NNE-SSW striking fault zone. In addition, a partly exposed dyke-like intrusion was found in a gorge along strike from the complex and about $1.2 \mathrm{~km}$ north-west of point 900 . The occurrence of numerous blocks of contaminated intermediate rocks with tabular jointing indicates that this is probably the uppermost part of a larger intrusion (see below).

About half a kilometre towards the east (figs 11, 13a and Plate 2), a transgressive sill or sheet with an orientation of $155 / 37^{\circ} \mathrm{SW}$ occurs in a downfaulted block in which only lavas of the plagioclase-augite-olivine-glomerophyric type are exposed. Assuming the direction of displacement to be vertical and that the sheet corresponds to a sill-like apophysis extending from one of the dyke-like intrusions (fig. 12) on the edge of the plateau at an altitude of $710 \mathrm{~m}$ then the downthrow must be at least $350 \mathrm{~m}$.

The lowermost exposures of the Hammers Dal Complex occur in the south-facing slopes of Hammers Dal $429 \mathrm{~m}$ above sea level whereas the uppermost part is exposed on point 900 about $2 \mathrm{~km}$ towards north-north-west. Due to the steep orientation of numerous elongate 'shale' xenoliths in the intermediate rock this part of the complex is believed to form a transition to a volcanic neck. This is in agreement with the suggestions of Pedersen (1975a)

* The altitudes used in this text are taken from the 1:50000 topographic map sheet $70 \mathrm{~V} .1 \mathrm{O}$. The altitudes in fig. 11 and Plate 2 were determined with the aid of a photogrammetrical technique (Dueholm, Pedersen \& Ulff-Møller, this report) and differ slightly from the published values.

2 Rapport nr. 81 
Fig. 12. Cross-section through the lower part of the Hammers Dal Complex perpendicular to the longitudinal axes of the intrusions. Orientation of cross-section is $65 / 82^{\circ} \mathrm{S}$. Lavas with ornamentation: plagioclase-augite-olivine-glomerophyric tholeiites; lavas without ornamentation: aphyric or slightly plagioclase-porphyric tholeiites.

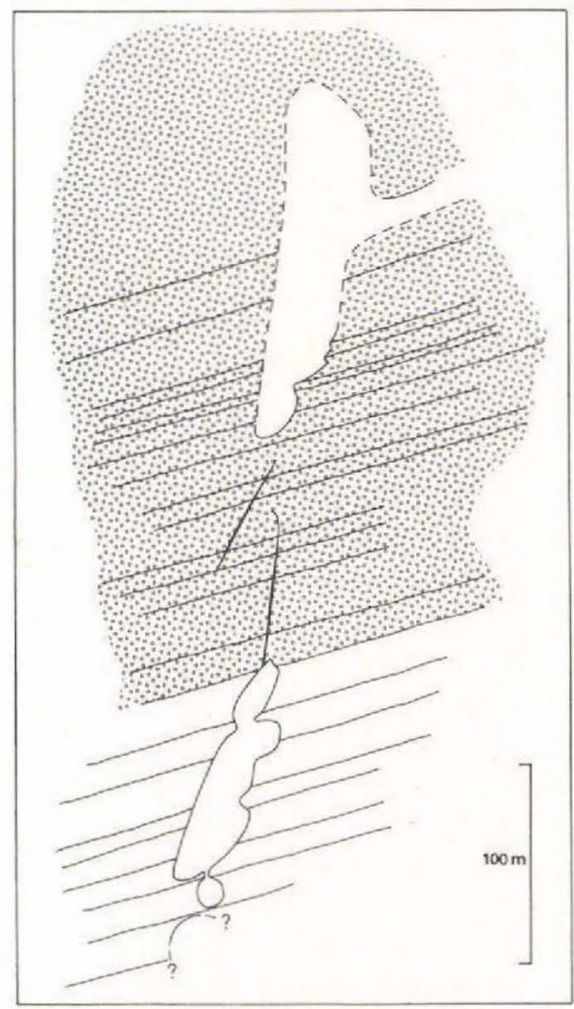

who found a few slightly contaminated lavas of the Nordfjord member on point 901 about $1.2 \mathrm{~km}$ towards the north-north-east indicating the proximity of the palaeosurface (fig. 10).

A detailed survey of the intrusions was carried out using advanced photogrammetrical methods (Dueholm, Pedersen \& Ulff-Møller, this report) on the basis of which the sections shown on figs 12 and 13 were constructed. The outline of the intrusive bodies range in shape from subhorizontal pipes with a diameter of $10-20 \mathrm{~m}$ to dyke-like intrusions which in cross-section are $30-40 \mathrm{~m}$ wide and extend vertically for $100 \mathrm{~m}$ or more. The longitudinal axes of the intrusions plunge approximately $8^{\circ}$ towards north-west. The dyke-like bodies are characterized by a relatively even hanging wall whereas the footwall consists of a number of shelves commonly formed by the scoriaceous part of the adjacent lavas. The scoria (not shown on figs 12 and 13) generally forms an irregular layer constituting the upper third or half of a lava flow. In adddition a thin scoria commonly forms the bottom part of each flow. In some cases the scoriae apparently were more resistant to abrasion by the incoming magma than the colonnades.

The intrusions are connected by $1-2 \mathrm{~m}$ wide dykes which are the only sign of dilation associated with the intrusion of the magma.

Intrusions which may resemble these occur at the margins of the Shonkin Sag laccolith, Montana, and are described by Pollard et al. (1975). These are described as numerous, parallel, tubular intrusive bodies up to $100 \mathrm{~m}$ long with a diameter of $1 \mathrm{~m}$ occurring as 
'fingers' which proceed from the termination of a sill intruding into sandstone and shale. The space for the intruding magma was obtained mainly by dilation and compaction of the material between the fingers whereas removal of the wall rock seems to be of subordinate importance. Although some similiarities exist between these and the dyke-like intrusions of the Hammers Dal Complex, the latter are developed on a much larger scale and removal of the wall rock seems to be a major factor in the formation of the intrusions. Dilation probably only took place in the initial stage of intrusion.

\section{The intrusive rocks}

When reasonably well exposed the larger intrusions always appear to be composite, comprising a marginal dolerite and centrally-situated, highly contaminated, intermediate rocks of variable composition. Reaction between an olivine tholeiitic magma and Cretaceous-Tertiary sediments (Pedersen, 1975a) took place in the formation of all these rock types. The small intrusions (the thin dykes) consist only of dolerite.

The following description is based mainly on observations made on the lower part of the Hammers Dal Complex which occurs in gorges in the south facing slope of Hammers Dal. These outcrops are the best exposed parts of the complex.

\section{The marginal dolerite}

The marginal dolerite is a dark greenish-grey rock of tholeiitic composition which formed by moderate contamination of an olivine tholeiitic magma. This rock forms a continuous fringe along the contacts, ranging in thickness between 1 and $4 \mathrm{~m}$ (fig. 13). Based on the content of inclusions this is divisible into several zones which are parallel to the contacts but which do not necessarily continue around the intrusions.

The dolerite is generally fine to medium grained being only slightly more fine grained at the contacts. Very fine grained or glassy chilled margins are not developed. In some cases the dolerite is even welded to the contact indicating that the wall rock was thoroughly heated by the magma before solidification started. This often impedes the exact localization of the contact. The dolerite contains scattered phenocrysts of olivine and bronzite in a matrix of plagioclase and high and low calcium clinopyroxenes arranged in an intergranular texture. The residuum in the interstices is characterized by fine ilmenite tabulae of needleshaped cross-section and equidimensional crystals, a few microns in size, of a brownishgrey spinel which is probably ulvöspinel. Together with a few sulphide blebs these are situated in a faint brownish glass matrix which contain several dark spherules of glass, 1-2 microns across. Similar spherules have been described by Roedder \& Weiblen (1971) and are ascribed to silicate-liquid immiscibility.

An olivine-enriched zone (not shown on fig. 13) $10-20 \mathrm{~cm}$ thick occurs in the dolerite on the bottom of the intrusions and on shelves in the footwall and is only found below the iron-rich cumulates. This zone was formed by gravitative accumulation of phenocrysts, xenoliths, and an immiscible sulphide liquid. The phenocrysts are: (a) short prismatic crystals of olivine $0.5-2 \mathrm{~cm}$ long with poorly developed crystal faces, some of which have nucleated around a core of a graphite-rich sediment xenolith; (b) skeletal crystals of olivine (Fosz determined by interpolation of Guinier data between olivines of known composition: 
Jahanbagloo, 1969) commonly 2-3 cm across (in rare cases up to $7 \mathrm{~cm}$ ); and (c) rare crystals of plagioclase.

The xenoliths are all 'shale' xenoliths, up to $10 \mathrm{~cm}$ in size, mainly of a very recrystallized and highly chemically equilibrated type. They consist of plagioclase, graphite and subordinate amounts of a red spinel very similar to xenoliths described by Törnebohm (1878) and Melson \& Switzer (1966). The xenoliths are often mantled by olivine or medium-grained norite or olivine norite slightly coarser than the doleritic matrix. Additionally $5-20 \mathrm{~cm}$ sized nodules of norite, ranging from medium to coarse grained, have been found. These are believed to be cognate (Pedersen, 1975b). The coarse-grained type, which contains tabular crystals of plagioclase $2-3 \mathrm{~cm}$ across, is very rare and has only been found in the northernmost part of the complex.

The sulphides occur as rounded blebs of troilite commonly $2-5 \mathrm{~mm}$ across, in many cases containing vermicular intergrowths of black material that appear to be weathering products of native iron. At certain places in the intrusive sheet lensoid bodies of troilite $1 \times 3 \mathrm{~cm}$ in size are found resting directly on the contact. Troilite is also sparsely disseminated throughout the dolerite.

An inclusion-poor zone occurs above the olivine-enriched zone (fig. 13). It contains the same spectrum of inclusions as the latter, but much more scattered, together with $5 \mathrm{~mm}$ sized bodies of iron intergrown with cohenite $\left(\mathrm{Fe}_{3} \mathrm{C}\right)$. Troilite occurs both as spherules, a few millimetres in size, and disseminated in the dolerite. Within this zone in the lower part of the upper dyke-like intrusion a $15 \mathrm{~cm}$ long, spongy body of ellipsoidal outline was found indicating that some of the iron apparently accumulated as large solid aggregates.

An iron-rich cumulate zone occurs $0.5-1 \mathrm{~m}$ above the bottom and shelves of the intrusions (fig. 13). This reaches a maximum thickness of $0.5-1.5 \mathrm{~m}$ but does not generally display any cumulate texture because the iron accumulated as solid spongy bodies which constitute 15-25 per cent by volume of a cumulate zone. Upwards and downwards the change from an iron cumulate to dolerite nearly free of native iron takes place within a few centimetres.

In the intrusive sheet the inclusion-poor zone is lacking and there is an overlap between the upper part of the olivine-enriched zone and the lower part of the iron cumulate. Scattered bodies of iron found in the dolerite above the cumulate indicates that the spongy bodies which accumulated characteristically range in size between 1 and $5 \mathrm{~cm}$.

Iron and iron cumulates will be described more thorougly in a later section.

A second inclusion-poor zone occurs above the iron-rich cumulate (fig. 13). Where the contacts are dipping steeply, both inclusion-poor zones grade laterally into dolerite with a very low content of inclusions. In these places this is the only rock type between the contact and the central intermediate rocks.

A strongly xenolith-enriched zone is found below the roofs and overhanging projections of the wall rock (fig. 13a, b). This was formed by accumulation of low density sediment xenoliths comprising 'shale' xenoliths of various degrees of recrystallization and chemical equilibration, and subordinate amounts of 'sandstone' xenoliths which at the time of intrusion were partially molten. The 'shale' xenoliths have often retained a tabular shape, whereas others certainly have suffered a high degree of rounding.

The xenolith cumulates generally form $0.5-1 \mathrm{~m}$ thick layers along the contacts, containing xenoliths in the range of 5-10 cm, but in the sheet an extreme accumulation occurred forming a 2-5 m thick densely packed layer of mainly tabular xenoliths $10-15 \mathrm{~cm}$ across. In 


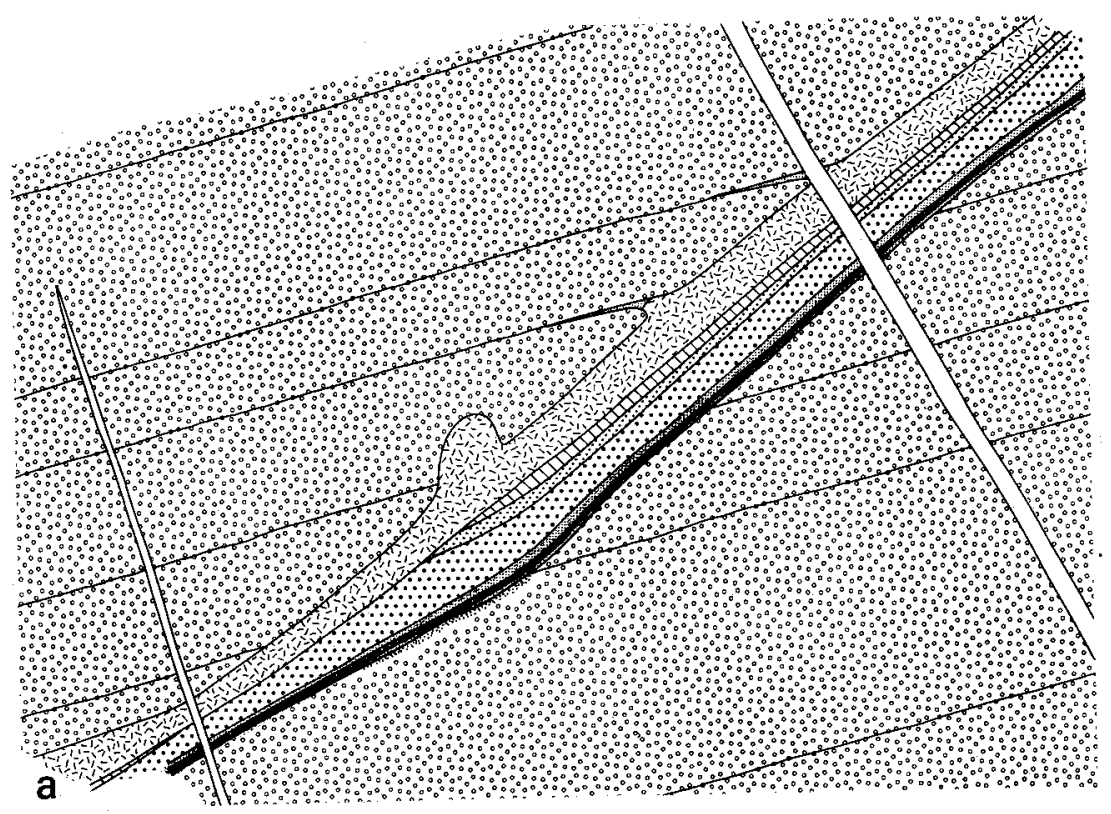

Fig. 13. Detailed sections through the best exposed parts of the Hammers Dal Complex, (a) the lower third of the intrusive sheet cut by two dykes, (b) the lower dyke-like intrusion and the pipe-like intrusion below and (c) the lower part of the upper dyke-like intrusion. For the relative position of these sections see fig. 11 and 12 .

a few places xenoliths of up to $1 \mathrm{~m}$ have been observed. Additionally 'sandstone' xenoliths with thin fragmented layers of 'shale' have been found together with rare, extremely graphite-rich xenoliths which probably originated from reaction with seams of brown coal. Rims of olivine or norite are either very thin or totally lacking. The doleritic matrix is commonly relatively rich in disseminated sulphides, mainly troilite. The xenoliths are either arbitrarily orientated or show a slightly preferred orientation parallel to the contact.

A cavity in the roof of the sheet (fig. 13a) only a few metres wide perpendicular to the profile section was also filled with the xenolith-rich magma which intruded along a joint. Where the magma intruded as thin wedges between the lavas the xenoliths were strained off.

A transition zone to the highly contaminated intermediate rocks is commonly $5 \mathrm{~cm}$ thick, though all stages between an abrupt and a gradual transition within a metre or so are developed. Near the bottom of the lower dyke-like intrusion (fig. 13b) $5-10 \mathrm{~cm}$ thick layers of highly contaminated intermediate rock alternate with the doleritic or a transitional rock.

In the upper end of the sheet the transition is abrupt and a distinct crack formed along the boundary during cooling. In the lower end of the sheet the transition is gradual within a zone of $5 \mathrm{~cm}$ which is strongly enriched in globules of iron ranging in size from less than 0.5 $\mathrm{mm}$ to $5 \mathrm{~mm}$. About $20 \mathrm{~m}$ from the lowermost exposed part of the sheet the iron zone grows increasingly diffuse so that the boundary is arbitrary. 

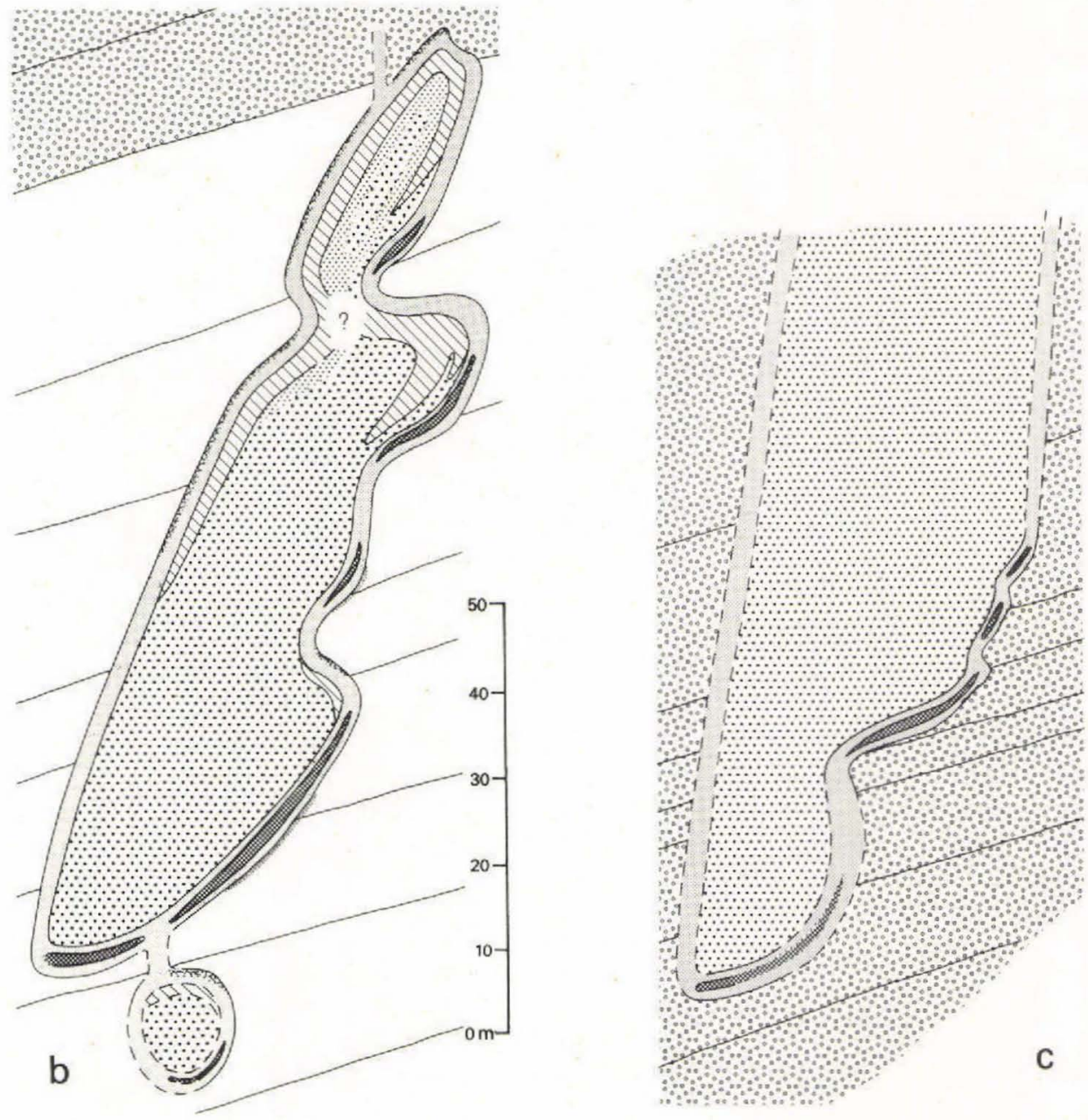

Dolerite

Native iron cumulate in dolerite

Xenoliths in doleritic matrix

Sulphide-mineralized scoria

Feldsparphyric tholeiitic lavas

Aphyric tholeiitic lavas

Xenolith-bearing intermediate rock

$\because \because \cdots \because$ with columnar jointing

with blocky jointing

with platy jointing 


\section{The central intermediate rocks}

Based on field observations the intermediate rocks are divided into three major types of which the predominant type (fig. 13 and Table 2) is characterized by well developed columnar jointing (fig. 14). The second type is characterized by blocky jointing which causes the rock to break down into small polyhedral blocks like the entablature of a lava, and the third type displays platy or tabular jointing.

Table 2. Area of cross-section of the intrusions and the relative abundances of the different rock types.

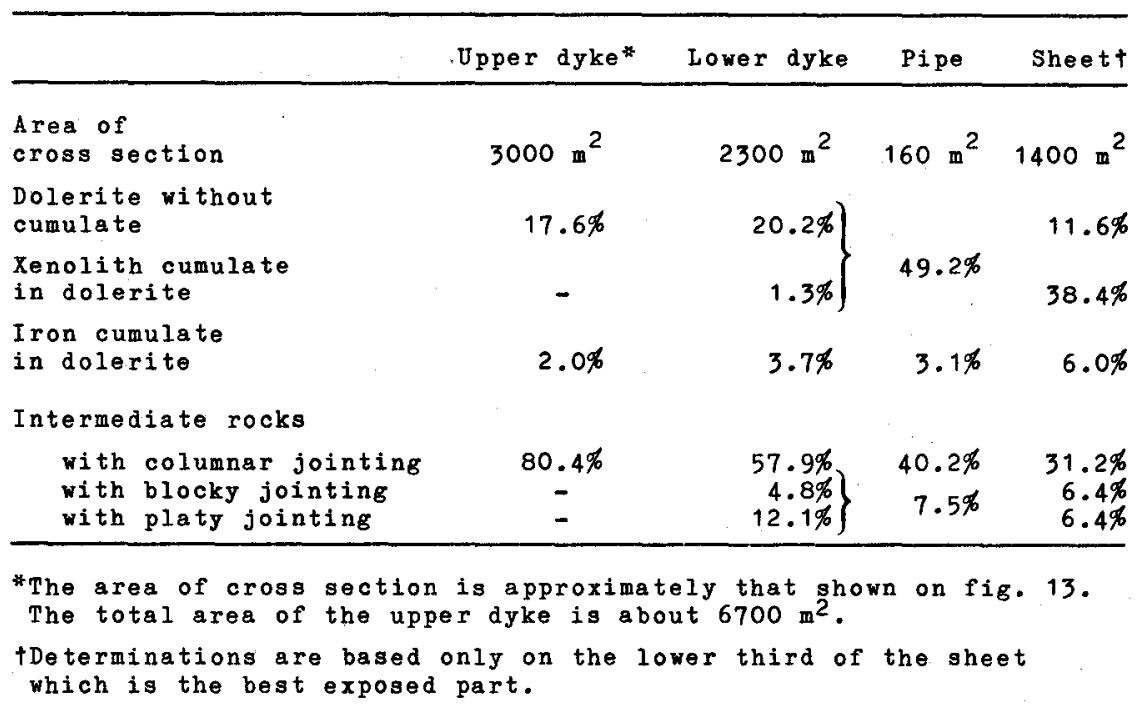

The intermediate rocks are, as earlier mentioned, highly contaminated rocks formed by reaction of an olivine tholeiitic magma with sandstone, shales and brown coal. The rocks are characterized by a large content of sediment xenoliths ranging in size from a few millimetres to $20 \mathrm{~cm}$, anhedral, irregular phenocrysts of plagioclase containing numerous inclusions, and numerous phenocrysts of reversely zoned prismatic bronzite which may reach a size of $2 \mathrm{~cm}$. The matrix is very fine-grained, dark grey or nearly black, consisting of plagioclase and clinopyroxene in intergranular intergrowth grading into zones of pilotaxitic or hyalopilitic texture. Taken as a whole the xenoliths seem to display a variation similar to those observed in the marginal dolerite. Some of the xenoliths are rimmed by mantles of medium-grained norite up to $1 \mathrm{~cm}$ thick.

Gravitational concentration of phenocrysts or sediment xenoliths, of which at least some must have a density differing from that of the magma, has not been observed, indicating that the intermediate magma was in a relatively viscous state at the time of intrusion. On weathered surfaces the matrix rock shows a very peculiar texture consisting of 1-2 mm sized, densely packed spherules. A similar texture has been observed in contaminated intermediate rocks at different stratigraphic levels in the Vaigat Formation at Asuk and in the valley of Kûgánguaq on north Disko. The origin of this texture is not known. 
Fig. 14. Photograph showing the lower part of the lower dyke-like intrusion. 1: inclusion-poor dolerite (an olivine-enriched zone occurs below but is not visible on the photograph. 2: iron-rich cumulate zone which reaches a maximum thickness of $1.5 \mathrm{~m} .3$ : inclusionpoor dolerite. 4: native iron bearing intermediate rock with columnar jointing filling out the central part of the intrusion.

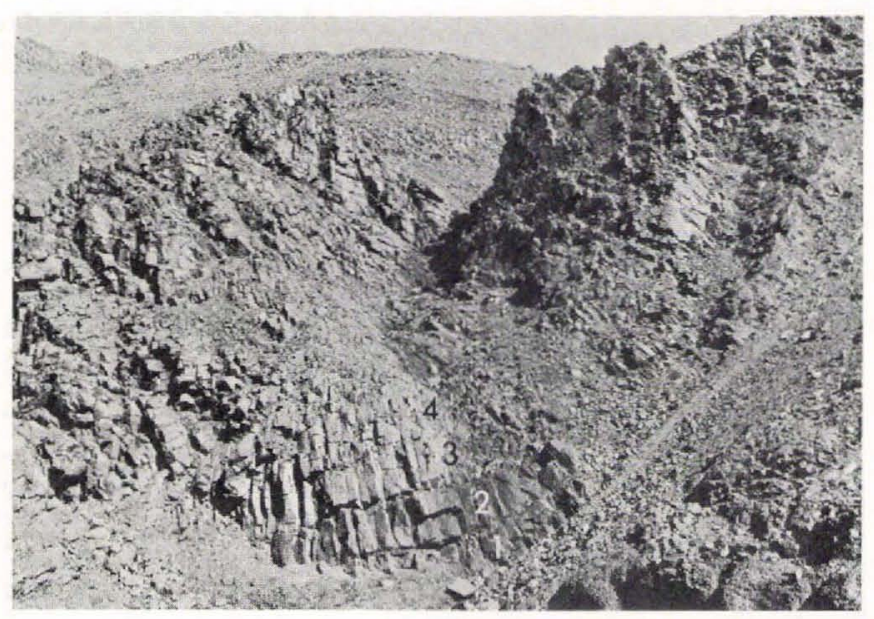

The different rock types are all characterized by a faint but distinct tar-like smell from fresh fracture surfaces.

The rock with columnar jointing is prevalent throughout the lower half of the individual intrusions (fig. 13), and contains xenoliths of very variable size, together with numerous troilite-rimmed globules of native iron varying in size from less than half a millimetre to about $1 \mathrm{~cm}$. Additionally numerous phenocrysts or granular aggregates of olivine displaying various degrees of resorption have been observed in thin sections. These are mantled by narrow fringes of bronzite.

With increasing size the shape of the iron globules varies from nearly perfect spheres through slightly elongate ellipsoids to irregular amoeboid bodies. The variation is thought to be the effect of surface tension acting on the globules which must have been at least partially molten at the time of intrusion. Other factors which may influence the shape of the spherules are dendritic growth of the metallic core and agglomeration of two or more spherules.

In the lower end of the sheet, where the boundary between the dolerite and the intermediate rock is hardly visible, the latter is developed as a somewhat lighter greyish variety. This is very poor in xenoliths and native iron but the spherular texture of the matrix rock seems to be just visible on weathered surfaces. A similar variety of this rock type has been observed in a dyke-like intrusion found by A. K. Pedersen south-west of point 440 (fig. 10) very near a volcanic neck.

The weights of separated fractions of several samples from the sheet and the lower dyke-like intrusion show a continuous increase from $1.7 \mathrm{wt}$. per cent native iron at the lower boundary to 2.3-2.5 wt. per cent in the central and upper part of the individual intrusions. This is in disagreement with the suggestion of gravitational concentration of native iron spherules (Ulff-Møller, 1975) which arose from the fact that these increase in size (which makes them more easily visible in hand specimen) but decrease in number towards the boundary to the marginal dolerite in the sheet and in the lower part of the lower dyke-like intrusion. The reason for this variation is not known but a lower viscosity may have favoured the agglomeration of small spherules. 
The upward and possibly inward increase of the native iron content in the intermediate rock could be explained by a progressive reduction, as suggested by Pedersen (1975b), to account for the reverse zoning of orthopyroxene observed in similar rocks.

The native iron content of similar rocks from the lower part of the upper dyke-like intrusion, from point 900 and the intrusion recently found $1.2 \mathrm{~km}$ north-west of this is 1.4 , 1.4 , and 0.4 wt. per cent respectively based on only one sample each.

The rock with blocky jointing seems to form a transition between the previous type and the type with platy jointing and is only found beneath the roof, forming a sheet between the two other xenolith-bearing intermediate rocks (fig. 13). The xenolithic content within this rock type seems to be slightly less than that of the rock with columnar jointing. The xenoliths generally range in size from 3 to $5 \mathrm{~cm}$ and appear to be well rounded, often ellipsoidal. The content of native iron is very low or even nil. Graphite-bearing globules 1-2 $\mathrm{mm}$ across occur in the matrix together with scattered troilite blebs of similar size. Numerous euhedral crystals of a red spinel not exceeding 50 microns, occur in the matrix. Apparently they crystallized from the magma, in contrast to much larger, irregular xenocrysts of red spinel which originated from disintegrated 'shale' xenoliths.

The rock with platy jointing occurs as a 1-3 m thick sheet beneath the roofs immediately below the dolerite, commonly in places where the latter contain accumulations of low density xenoliths (fig. 13). The inclusions are dominated by $1-3 \mathrm{~cm}$ sized xenoliths which occur in smaller amounts than within the rock with blocky jointing and like this the matrix contains spherules of troilite, graphite-bearing globules and small grains of red spinel whereas native iron is lacking.

The two latter rock types are so much alike that they actually may be identical and the differences in jointing may arise from differences in cooling rates. The intermediate rocks grade into each other through $10-20 \mathrm{~cm}$ wide transition zones whereas the boundary between the rock with platy jointing and the marginal dolerite appears to be sharp. A slight accumulation of a few millimetre-sized bodies of iron within the dolerite just above this boundary indicates that at least a part of the marginal basaltic magma was still fluid at the time of intrusion of the intermediate magma. The reason for this concentration of the two subordinate intermediate rock types beneath the roofs is thought to be due to a lower density than that of the iron-bearing rock. A density contrast may also have caused the uplift of the two tongues of these rock types within the iron-bearing rock at the footwall of the lower dyke-like intrusion (fig. 13b).

\section{Wall rock interactions}

As mentioned above the wall rock was thoroughly heated before the solidification of the magma started with the consequence that there was conspicuous wall rock mineralization and remelting of tuffaceous material.

\section{Mineralized scoriae}

Due to the hot wall rock the immiscible sulphide liquid, which concentrated on the bottom and on the shelves of the intrusions, was able to penetrate into the scoriaceous part of the lavas totally filling out the vesicles. This has been noticed in two places in the lower 
dyke-like intrusion (fig. 13b) but due to poor exposure the maximum depth of penetration is not known. The same type of wall rock mineralization is developed on a much larger scale at the lower end of the sheet where this cuts the lavas at a low angle (fig. 13a). In this place the scoriaceous part of the lava is very porous and has consequently been heavily mineralized down to $60 \mathrm{~cm}$ below the contact.

Towards the lower end of the sheet the mineralization continues for about $20 \mathrm{~m}$ and gradually wedges out. In polished samples and even in hand samples the mineralization displays a distinct zoning. The zone nearest to the contact is about $50 \mathrm{~cm}$ thick and is dominated by troilite intergrown with amoeboid bodies of native iron and subordinate ilmenite and ulvöspinel. The iron has practically disappeared due to weathering and is replaced by dark alteration products. The nickel and cobalt which occurred in solid solution in the iron reacted with troilite to form pentlandite, which occurs as a rim in the troilite, preserving the original outline of the metal grain. Within this zone, the amount of ulvöspinel relative to ilmenite increases downwards.

In the outer zone of the mineralization any signs of a metallic phase are lacking. In contrast, pentlandite, of a textural type which is not a result of weathering, and a copperiron sulphide occur in increasing amount towards the outer boundary of the mineralization. Galena occurs as an accessory constituent. Both pentlandite and the copper-iron sulphide contain exsolution lamellae of each other.

Apparently this mineralization was formed by a metal-rich sulphide melt (Craig \& Kullerud, 1969) containing some nickel and minor amounts of copper which crystallized in a temperature and oxygen fugacity gradient. These factors caused fractional crystallization colaterally with oxidation of the melt leading to the disappearance of the metallic phase as a component and to the final concentration of nickel, copper and lead in the residual melt. The intergrowth of ilmenite and ulvöspinel with troilite are believed to be an effect of remobilization and reduction of the pre-existing iron-titanium oxides in the lava forming the wall rock.

Judged from the mineral assemblages the minimum temperature of the wall rock must have been about $1000^{\circ} \mathrm{C}$ at the contact decreasing to about $850^{\circ} \mathrm{C}$ at the lower boundary of the mineralization (Craig \& Kullerud, 1969).

The occurrence of nearly fresh olivine in the plagioclase-augite-olivine glomerophyres within the mineralized part of the scoria, while olivine in the lavas elsewhere in the area is heavily altered, shows that wall rock mineralization took place before alteration of olivine which probably happened simultaneously with the infilling of vesicles with zeolites. Apparently iron and troilite had a buffering influence on the circulating hydrous solutions thereby creating conditions favouring preservation of olivine.

The mineralized scoria is the subject of a detailed study by H. K. Schönwandt and F. Ulff-Møller.

\section{Remelted tuff}

Another effect of the heating of the wall rock was a partial or nearly total remelting of fine-grained tuffaceous material. This material forms irregular layers $10-20 \mathrm{~cm}$ thick between the lavas and is thought to be in some cases oxidized and probably weathered tuff. The melt generated in this way flowed as tongues along the lower contacts where it solidified as a fine-grained rock. The mineralized scoria below the sheet is directly covered 
by such a $20 \mathrm{~cm}$ thick, fine-grained, plagioclase-olivine porphyritic rock containing up to 1 $\mathrm{cm}$ sized globules of troilite intergrown with iron. These have in some cases been drawn out to stringers as a consequence of flow. This rock forms a continuous sheet which extends to the lower end of the intrusive sheet for more than $40 \mathrm{~m}$ (not shown on fig. 13a). In addition a $5-10 \mathrm{~cm}$ thick rim of a similar plagioclase-porphyritic rock was observed around the xenolith-filled cavity in the roof.

At the contact below the iron cumulates in the upper dyke-like intrusion such a $25 \mathrm{~cm}$ thick flow of remobilised tuff was quenched to opaque, dark bluish-grey glass becoming gradually more crystalline away from the contact.

A similar example of partial melting of tuffaceous material has been observed around an $8 \mathrm{~m}$ wide dyke not belonging to the Hammers Dal Complex.

\section{The native iron}

The main part of the native iron in the rocks of the Hammers Dal Complex is roughly divided into two major types: iron which forms cumulates in the marginal dolerite and iron spherules in the intermediate rock characterized by columnar jointing.

\section{The iron cumulates}

In the pipes and the dyke-like intrusions the iron cumulates form zones of sickle-shaped cross-section (fig. 13b, c) composed mainly of iron, troilite and cohenite $\left(\mathrm{Fe}_{3} \mathrm{C}\right)$ of which the latter exsolved from the iron during cooling. These opaque minerals, which are embedded in a doleritic matrix sparsely disseminated with troilite, make up 15-25 per cent by volume of a cumulate zone. Accessory constituents are ilmenite, ulvöspinel, pentlandite and a copper-iron sulphide of which the latter two exsolved from the troilite.

The iron cumulates are somewhat arbitrarily divided into a lower troilite-rich zone which comprises 10-50 per cent by volume of the cumulate and an upper zone dominated by iron in which troilite is the most important of the minor constituents.

The thickness of the cumulates is strongly dependent on the dip of the underlying shelf but characteristically the maximum thickness obtained ranges between 0.5 and $1.5 \mathrm{~m}$. The cumulates gradually wedge out and totally disappear where the dip of the adjacent contact exceeds about $75^{\circ}$. The troilite-rich zone is the last zone to wedge out and around the termination of the cumulate the dolerite is heavily mineralized with disseminated troilite. This means that the accumulation was able to take place on sloping surfaces with a dip not exceeding $60^{\circ}$ and that the troilite-rich bodies, which at that time probably consisted of a solid core of iron enclosed in a metal-rich sulphide melt, were able to accumulate on more steeply sloping surfaces than the spongy bodies of iron which formed the upper part of the cumulate zones. (The Fe-FeS system comprises a eutectic point at 31 wt. per cent $\mathrm{S}$ and $988^{\circ} \mathrm{C}$ (Hansen \& Anderko, 1958) corresponding to about 9.6 and 90.4 per cent by volume of iron and troilite respectively.)

Resistance measurements conducted in the laboratory on specimens up to $40 \mathrm{~cm}$ in size show a very low resistance indicating that to a large extent the iron bodies are connected both in the troilite-rich and in the iron-rich part of the cumulates. Actually the cumulates are thought to be highly conductive from the top to the bottom whereas columnar jointing probably reduces the conductivity considerably in the lateral direction. 
The connection of the iron bodies would also result in a high thermal conductivity which probably promoted cooling and thereby the solidification of the basaltic magma in and above the cumulate zones. This may explain the strongly increased thickness of the marginal dolerite in these places.

In the sheet (fig. 13a) the iron cumulate is continuous, ranging in thickness between 50 and $75 \mathrm{~cm}$.

In the troilite-rich lower zone of the iron cumulates the iron occurs both as irregular bodies, some millimetres in size (fig. 15), and as poorly developed dendrites in a matrix commonly consisting of not more than three of four crystals of troilite forming $1-2 \mathrm{~cm}$ large irregular bodies. The iron occurs as a perlitic intergrowth with cohenite (fig. 15). This characteristic texture which is formed by an eutectoid transformation (Hansen \& Anderko, 1958) classifies the iron in the group of low carbon steels in contrast to the well known iron from Uivfaq, south Disko which is classified as the carbon-rich type, 'white cast iron' (Löfquist \& Benedicks, 1940; Pauly, 1969). In addition the iron contains perfect spherules of troilite some $10-20$ microns in size.

The troilite enclosing the iron bodies contains small amounts of short crystalls of ilmenite of slightly rounded outline. These are several orders of magnitude larger than the fine tabular crystals of ilmenite in the doleritic matrix. In some cases the coarse ilmenite in the troilite is overgrown by a broad rim of ulvöspinel. Additional, tangentially-arranged, tabular crystals of ilmenite of intermediate size occur on the boundary between the iron-troilite bodies and the surrounding dolerite.

The amount of troilite decreases considerably upwards whereas the carbon content of the iron seems to be relatively constant or increases slightly. In the iron-rich zone troilite forms thin discontinuous rims around the branches of the iron bodies which are commonly about $5 \mathrm{~mm}$ across. The iron still contains small scattered spherules of troilite but no dendrites are developed. Ilmenite, but no ulvöspinel is present in the troilite around the iron bodies.

Fig. 15. Microphotograph showing a part of an irontroilite body from the lower troilite-rich part of an ironcumulate zone. White: iron with fine exsolution lamellae of cohenite (only visible in the upper and right part of the photograph), an arrow shows a narrow, irregular fringe of iron containing no cohenite exsolutions. Grey: troilite with numerous cracks both as rounded inclusions in the iron and surrounding the iron body. Black: plagioclase and pyroxene of the surrounding dolerite. Bar scale

$1 \mathrm{~mm}$. GGU 175954.10.

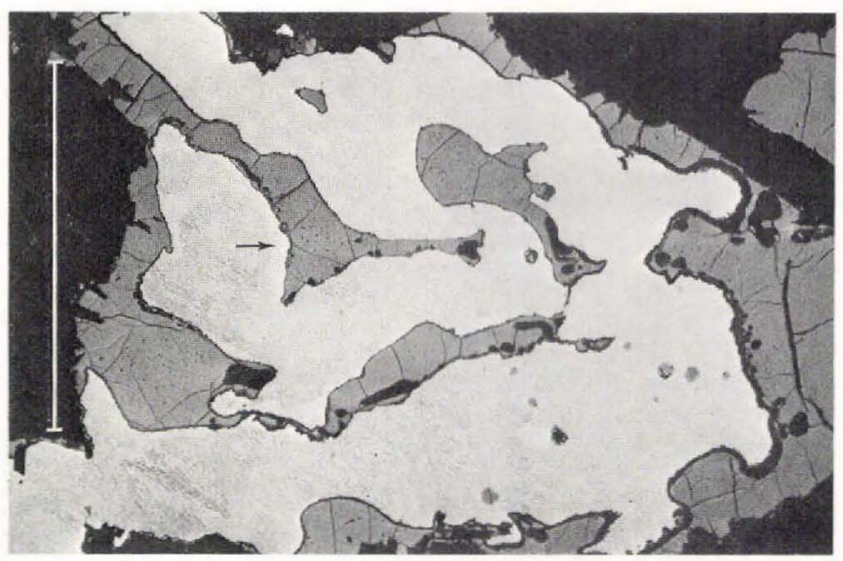


Table 3. Trace elements in iron from the iron-rich zone of the cumulate

\begin{tabular}{lrl}
\hline $\mathrm{Fe}$ & 103.00 weight $\%$ & $\mathrm{Rb} \sim 2 \mathrm{ppm}$ \\
$\mathrm{Ni}$ & 1.04 weight $\%$ & $\mathrm{Sr} \sim 14 \mathrm{ppm}$ \\
$\mathrm{Ca}$ & 0.12 weight $\%$ & $\mathrm{Y} \sim 3 \mathrm{ppm}$ \\
$\mathrm{Ga}$ & $45 \mathrm{ppm}$ & $\mathrm{Zr} \sim 20 \mathrm{ppm}$ \\
$\mathrm{Ge}$ & $58 \mathrm{ppm}$ & $\mathrm{Ag} \sim 3 \mathrm{ppm}$ \\
$\mathrm{As} \quad 150 \mathrm{ppm}$ & $\mathrm{Sb} \sim 3 \mathrm{ppm}$ \\
$\mathrm{Mo} \quad 35 \mathrm{ppm}$ & $\mathrm{Pb}<5 \mathrm{ppm}$ \\
$\mathrm{Sn}$ & $16 \mathrm{ppm}$ & \\
\hline
\end{tabular}

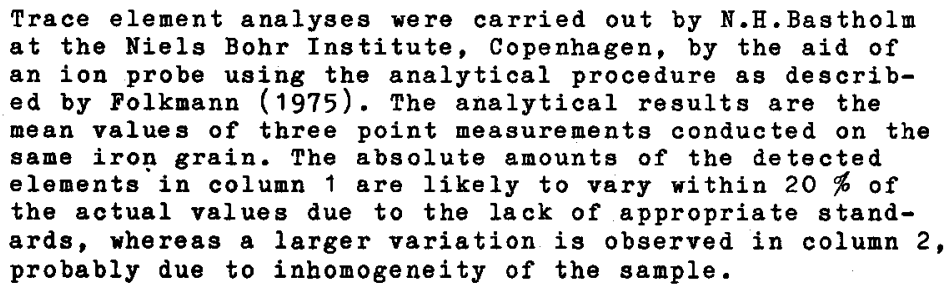

The low carbon content of the iron is confirmed by an analysis kindly provided by $\mathrm{J}$. Beyerholm (Det Danske Staalvalseværk A/S, Frederiksværk) which showed a content of 0.65 wt. per cent $C$ in iron from the central part of the iron-rich zone (GGU 175958) in the lower iron cumulate of the lower dyke-like intrusion. Iron from the lower part of the same zone contains $1.3 \mathrm{wt}$. per cent $\mathrm{Ni}$ and $0.6 \mathrm{wt}$. per cent $\mathrm{Co}$ according to a partial microprobe analysis (GGU175955.30) but these values need not necessarily be representative of the cumulates. Trace element analysis was conducted on iron from GGU sample 175958 (Table 3).

Based on the detailed survey of the intrusions it appears that the amount of iron concentrated in the iron cumulates relative to the volume of the particular intrusion is fairly constant - about 0.5 per cent by volume corresponding to $1.1-1.3$ per cent by weight.

\section{Iron spherules in the intermediate rock}

The iron spherules characteristically consist of a core of iron with subordinate cohenite rimmed by troilite which may constitute up to about 10 per cent by volume of the spherule (fig. 16). In numerous cases a eutectic intergrowth of schreibersite $\left(\mathrm{Fe}_{3} \mathrm{P}\right)$, cohenite and iron are observed between the troilite rim and the metallic core forming an arcuate shield or cap on one side of the spherules. In addition a rim of cohenite may occur between the metallic core and the troilite rim or phosphide eutectic when this is present.

An analysis made by $\mathrm{J}$. Beyerholm indicated $1.4 \mathrm{wt}$. per cent $\mathrm{C}$ in a separation of iron spherules from GGU 175990 containing iron, cohenite, and schreibersite but virtually no troilite (fig. 16).

At the boundary between the central intermediate rocks and the marginal dolerite whether an iron-enriched zone is developed or not - the phosphide eutectics are nearly 
lacking; the iron spherules are developed as metal cores with a fine perlitic texture surrounded by broad irregular fringes of cohenite which are intergrown with plagioclase of the surrounding intermediate rock. Troilite then occurs only in very subordinate amounts. In some cases spherules consisting only of phosphide eutectics are present. These were probably formed by mechanical separation of the molten part of the spherules from the solid cores of iron.

\section{The iron as a potential ore}

If the intrusions are assumed to be representative of the Hammers Dal Complex as a whole and if the complex is assumed to extend continuously up to $1.2 \mathrm{~km}$ north-west of point 900 then the volume of the intrusive rocks above sea level will be about $0.06 \mathrm{~km}^{3}$. The amount of native iron concentrated within cumulate zones in the marginal dolerite will then be about 2.3 million tons of native iron of a low carbon and low phosphorus type relatively rich in sulphur. If the iron-bearing intermediate rock is assumed to make up 70 per cent by volume of the intrusions and to contain a mean of $2 \mathrm{wt}$. per cent of native iron then this rock will contain 2.8 million tons of native iron of a high phosphorus, high carbon, but probably low sulphur type which is relatively evenly distributed throughout the rock.

As wall rock mineralization is very dependent on the porosity of the wall rock, its volume is difficult to estimate. If the mineralized scoria below the sheet is assumed to extend for $100 \mathrm{~m}$ then the amount of sulphide minerals present is only about 500 tons. Even though greater mineralization is likely to occur at the bottom in the dyke-like intrusions as bodies of massive sulphide ore, in places where the conditions of deposition are favourable, the content of elements of economic importance is probably relatively low so that this type of mineralization is considered as economically insignifcant.

Fig. 16. Microphotograph of an iron spherule from the intermediate rock with columnar jointing. Light grey: iron with irregular exsolution bodies of cohenite (hardly visible); polygonal intergrowths of cohenite grains form irregular fringes along the margins of the individual iron grains. Medium grey: eutectic intergrowth of schreibersite $\left(\mathrm{Fe}_{3} \mathrm{P}\right)$, cohenite, iron and troilite. Dark grey: troilite with numerous cracks. Black: plagioclase and pyroxene of the surrounding intermediate rock. Arrows show a thin rim of cohenite along the margin of the spherule. Length of spherule about $2 \mathrm{~mm}$, polarized light, GGU 175990.

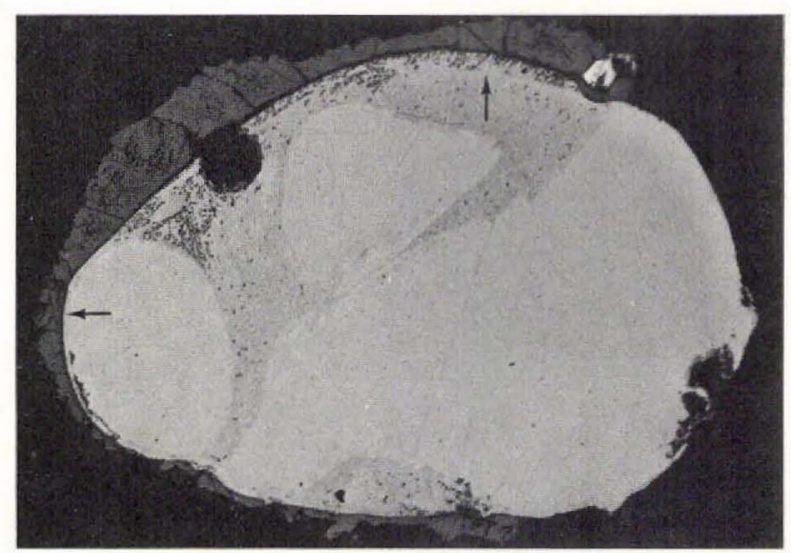


Table 4. Major and minor element compositions of the two main types of native iron

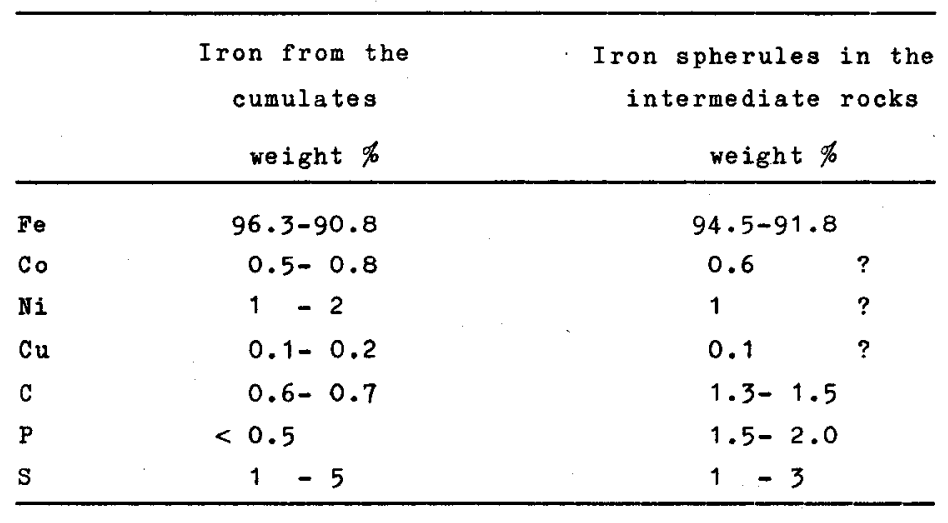

The estimates are based on petrographic observations.

These estimates are based on the assumption that there is no significant lateral variation. Since the area north-west of the Hammers Dal Complex is regarded as the centre of much of the related volcanic activity, an increase in the amount of native iron in the cumulate zones towards the north-north-west is very likely, whereas the iron content of the intermediate rock is believed not to show any notable regional variation. Unfortunately no evidence of the direction of lateral flow through the intrusions has been found.

Weathering may also considerably affect the amount of ore, as iron is one of the first minerals to disappear.

Elements of potential economic interest in the iron may be $\mathrm{Co}, \mathrm{Ni}, \mathrm{Cu}, \mathrm{Pt}$ and possibly some of the other noble metals (Tables 4 and 5). The contents of sulphur, phosphorus and carbon are important if the native iron is considered for steel manufacture. The approximate compositions of the two types of iron are given in Tables 4 and 5. Magnetic separations with

Table 5. Noble metal content of the two types of native iron

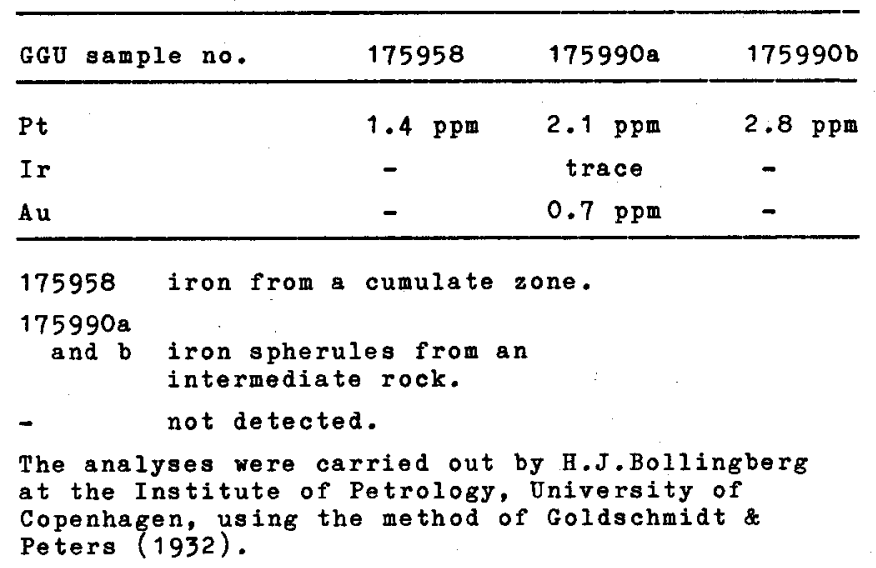


these compositions could be obtained relatively easily and further mechanical treatment could reduce the sulphur content of both iron types below $0.1-0.2$ per cent by weight. In addition the content of carbon and phosphorus of the iron spherules could be reduced in the same way to about 1.2 per cent and 1.1 per cent by weight respectively due to the brittleness of these minerals.

The physical properties of the rocks - especially the high conductivity of both iron cumulates, xenolith cumulates beneath the roofs and mineralized scoriae - may facilitate the subsurface mapping of the intrusions by electro-magnetic methods.

\section{Summary}

(1) Apparently the formation of the Hammers Dal Complex took place during a violent initial event during which the thin dykes were formed. Basaltic magma flowing laterally through these tensional openings caused the removal of certain parts of the wall rock resulting in the formation of the final outline of the individual intrusions.

(2) The second stage is characterized by continued flow with gradually decreasing velocity removing all lava xenoliths, of which actually none have been found. This also caused heating of the wall rock. The immiscible sulphide melt which flowed along the floor of the intrusions was thereby able to ooze into the scoriaceous parts of the adjacent lavas and the liquefied tuffaceous material flowed out forming tongues along the lower contacts.

(3) When the velocity of flow had reached a relatively low level the solidification of the basaltic magma started, whereby blebs of suspended sulphide liquid, olivine phenocrysts and 'heavy' xenoliths settled contemporaneously with the rise of light xenoliths leading to the formation of the olivine-enriched zone at the bottom and xenolith cumulates beneath the roofs and overhanging projections of the wall rock. After this the accumulation of 'heavy' material apparently stagnated in the dyke-like intrusions while the solidification of up to $1 \mathrm{~m}$ of dolerite took place.

(4) A new pulse of basaltic magma loaded with spongy iron bodies intruded indicating an increase of flow rate. This resulted in the formation of the iron cumulates. The troilite-rich lower part of these may either indicate that the initial part of that pulse was sulphide-rich or that the zoning is a result of selective gravitational settling of the suspended bodies.

(5) As the upper part of the iron cumulates are abruptly truncated the basaltic magma was probably displaced by the intrusion of the intermediate magma which prevented further precipitation of native iron. Consequently the remaining part of the basaltic magma solidified to a rock containing only scattered bodies of iron of which some precipitated on top of the intermediate magma while this was probably still fluid.

(6) The zoning within the iron-bearing intermediate rock could be an indication of continued flow after the intrusion and partial solidification of the intermediate magmas.

\section{Acknowledgements}

A. K. Pedersen (Geological Museum) and C. K. Brooks (Institute of Geology, University of Copenhagen) kindly read the manuscript and made valuable suggestions for improvements. 


\section{References}

Craig, J. R. \& Kullerud, G. 1969: Phase relations in the Cu-Fe-Ni-S system and their application to magmatic ore deposits. Econ. Geol. Mono. 4, 344-358.

Folkmann, F. 1975: Analytical use of ion-induced x rays. J. Phys. E 8, 429-444.

Goldschmidt, V. M. \& Peters, C. 1932: Zur Geochemie der Edelmetalle. Nachr. Ges. Wiss. Göttingen, Math.-Phys. Kl., 1932, 377-401.

Hald, N. \& Pedersen, A. K. 1975: Lithostratigraphy of the early Tertiary volcanic rocks of central West Greenland. Rapp. Grønlands geol. Unders. 69, 17-24.

Hansen, M. \& Anderko, K. 1958: Constitution of binary alloys. 1305 pp. New York: McGraw-Hill. Jahanbagloo, J. C. 1969: X-ray diffraction study of olivine solid solution series. Am. Miner. 54, 246-250.

Löfquist, H. \& Benedicks, C. 1940: Det stora Nordenskiöldska järnblocket från Ovifaq, dess mikrografi och metallurgi. Jernkontor. annal. 124, 633-685.

Melson, W. G. \& Switzer, G. 1966: Plagioclase-spinel-graphite xenoliths in metallic iron-bearing basalts, Disko Island, Greenland. Am. Miner. 51, 664-676.

Münther, V. 1952: Grafitbasalten i NV-Disko. Meddr dansk geol. Foren. 12, 159-160.

Münther, V. 1973: Results from a geological reconnaissance around Svartenhuk Halvø, West Greenland. Rapp. Grønlands geol. Unders. 50, 26 pp.

Pauly, H. 1969: White cast iron with cohenite, schreibersite and sulphides from Tertiary basalts on Disko, Greenland. Meddr dansk geol. Foren. 19, 8-26.

Pedersen, A. K. 1973: Report on field work along the north coast of Disko, 1971. Rapp. Grønlands geol. Unders. 53, 21-27.

Pedersen, A. K. 1975a: New mapping in north-western Disko 1972. Rapp. Grønlands geol. Unders. 69, 25-32.

Pedersen, A. K. 1975b: New investigations of the native iron bearing volcanic rocks of Disko, central West Greenland. Rapp. Grønlands geol. Unders. 75, 48-51.

Pollard, D. D., Muller, O. H. \& Dockstader, D. R. 1975: The form and growth of fingered sheet intrusions. Bull. geol. Soc. Am. 86, 351-363.

Roedder, E. \& Weiblen, P. W. 1971: Petrology of silicate melt inclusions, Apollo 11 and Apollo 12 and terrestrial equivalents. Proc. Second Lunar Sci. Conf. 1, 507-528.

Törnebohm, A. E. 1878: Über die Eisenführende Gesteine von Ovifak und Assuk in Grönland. Bih. K. svenska VetenskAkad. Handl.5,10, 22 pp.

Ulff-Møller, F. 1975: High temperature pyrrhotite and telluric iron mineralisations in western Disko, central West Greenland. Rapp. Grønlands geol. Unders. 75, 51-53. 